\title{
Article \\ The Structural Characterization and Antipathogenic Activities of Quinoin, a Type 1 Ribosome-Inactivating Protein from Quinoa Seeds
}

\author{
Sara Ragucci $^{1}{ }^{(\mathbb{D}}$, Daniela Bulgari ${ }^{2}{ }^{(D}$, Nicola Landi ${ }^{1}$, Rosita Russo $^{1}\left(\mathbb{D}\right.$, Angela Clemente ${ }^{1}$, Mariangela Valletta ${ }^{1}$ \\ Angela Chambery ${ }^{1}\left(\mathbb{D}\right.$, Emanuela Gobbi ${ }^{2} \mathbb{D}$, Franco Faoro ${ }^{3} \mathbb{D}$ and Antimo Di Maro ${ }^{1, *(D)}$
}

1 Department of Environmental, Biological and Pharmaceutical Sciences and Technologies (DiSTABiF), University of Campania 'Luigi Vanvitelli', Via Vivaldi 43, 81100 Caserta, Italy; sara.ragucci@unicampania.it (S.R.); nicola.landi@unicampania.it (N.L.); rosita.russo@unicampania.i (R.R.); angela.clemente@unicampania.it (A.C.); mariangela.valletta@unicampania.it (M.V.); angela.chambery@unicampania.it (A.C.)

2 Agri-Food and Environmental Microbiology Platform (PiMiAA), Department of Molecular and Translational Medicine, University of Brescia, Viale Europa 11, 25123 Brescia, Italy; daniela.bulgari@unibs.it (D.B.); emanuela.gobbi@unibs.it (E.G.)

3 Department of Agricultural and Environmental Sciences, University of Milan, Via Celoria 2, 20133 Milan, Italy; franco.faoro@unimi.it

* Correspondence: antimo.dimaro@unicampania.it; Tel.: +39-0823-274409

\section{check for}

updates

Citation: Ragucci, S.; Bulgari, D.; Landi, N.; Russo, R.; Clemente, A.; Valletta, M.; Chambery, A.; Gobbi, E.; Faoro, F.; Di Maro, A. The Structural Characterization and Antipathogenic Activities of Quinoin, a Type 1 Ribosome-Inactivating Protein from Quinoa Seeds. Int. J. Mol. Sci. 2021, 22, 8964. https://doi.org/10.3390/ ijms22168964

Academic Editor: Claudiu T. Supuran

Received: 27 July 2021

Accepted: 18 August 2021

Published: 20 August 2021

Publisher's Note: MDPI stays neutral with regard to jurisdictional claims in published maps and institutional affiliations.

Copyright: (c) 2021 by the authors. Licensee MDPI, Basel, Switzerland. This article is an open access article distributed under the terms and conditions of the Creative Commons Attribution (CC BY) license (https:/ / creativecommons.org/licenses/by/ $4.0 /)$.
Abstract: Quinoin is a type 1 ribosome-inactivating protein (RIP) we previously isolated from the seeds of pseudocereal quinoa (Chenopodium quinoa) and is known as a functional food for its beneficial effects on human health. As the presence of RIPs in edible plants could be potentially risky, here we further characterised biochemically the protein (complete amino acid sequence, homologies/differences with other RIPs and three-dimensional homology modeling) and explored its possible defensive role against pathogens. Quinoin consists of 254 amino acid residues, without cysteinyl residues. As demonstrated by similarities and homology modeling, quinoin preserves the amino acid residues of the active site (Tyr75, Tyr122, Glu177, Arg180, Phe181 and Trp206; quinoin numbering) and the RIP-fold characteristic of RIPs. The polypeptide chain of quinoin contains two $\mathrm{N}$-glycosylation sites at Asn115 and Asp231, the second of which appears to be linked to sugars. Moreover, by comparative MALDI-TOF tryptic peptide mapping, two differently glycosylated forms of quinoin, named pre-quinoin- 1 and pre-quinoin- $2(\sim 0.11 \mathrm{mg} / 100 \mathrm{~g}$ and $\sim 0.85 \mathrm{mg} / 100 \mathrm{~g}$ of seeds, respectively) were characterised. Finally, quinoin possesses: (i) strong antiviral activity, both in vitro and in vivo towards Tobacco Necrosis Virus (TNV); (ii) a growth inhibition effect on the bacterial pathogens of plants; and (iii) a slight antifungal effect against two Cryphonectria parasitica strains.

Keywords: amino acid sequence; Chenopodium quinoa Willd; plant pathogens; protein purification; Tobacco Necrosis Virus

\section{Introduction}

Ribosome-inactivating proteins (RIPs) are a group of specific toxins that inhibit protein synthesis [1]. This inhibition is a consequence of ribosome injury due to the enzymatic activity of RIPs, which makes ribosomes unable to interact with transcription factors such as the elongation factor 2 (EF-2, in eukaryotes) or the elongation factor G (EF-G, in prokaryotes), thus blocking the translocation processes [2]. In particular, the enzymatic action of RIPs results in the cleavage of a specific adenine residue $\left(\mathrm{A}_{4324}\right.$ in rat) in a conserved site of the 28S rRNA, known as the Sarcin Ricin Loop (SRL), for which they are classified as rRNA N-glycosylase (EC: 3.2.2.22) [3]. The specific enzymatic action of RIPs promotes cell death by apoptosis through the activation of caspases and caspase-like activities as well as the poly(ADP-ribose) polymerase cleavage [4]. In addition, several 
RIPs remove adenines from different nucleic acids (poly(A), DNA, RNA and virus RNA), for which these enzymes are described as adenine polynucleotide glycosylases (APG) [5].

RIPs are found in a large number of plants (flowering plants or Angiosperms) [6] and are distributed in different plant tissues (seeds, roots, leaves and bark) [5], although novel findings have highlighted their presence in fungi [7] and metazoan [8], while analogous enzymatic activities (the Shiga-like toxin) have been investigated for a long time in bacteria [9].

RIPs are classified into type 1 or 2 according to the presence or absence of a quaternary structure. Type 1 RIPs are single-chain proteins ( 30-kDa with a basic $\mathrm{pI})$ that possess rRNA N-glycosylase activity, while dimeric type 2 RIPs consist of an A-chain ( 30-kDa) endowed with enzymatic activity, linked to a B-chain $(\sim 34-\mathrm{kDa})$ with lectin properties and are able to bind oligosaccharides containing galactose moieties [10]. Furthermore, a novel group known as type 3 RIPs has been proposed, with the peculiar structural characteristics of this member (i.e., maize b-32 from maize endosperm and bRIP from barley). RIPs of this new group are synthesised as single domain proenzymes and are subsequently subjected to post-translational changes [11].

To date, the biological role of RIPs is still unknown, although different reports indicate that they may be involved in host defence activities, suggesting that these toxins are functional in conferring a fitness advantage [11]. On the other hand, the interest in these enzymes is due to their potential use for the treatment of several human diseases such as tumours, their employment in the construction of immunotoxins/nanoconstructs to obtain specificity $[4,12,13]$ or in plant biotechnology applications to improve resistance against pathogens [11,14], particularly viruses [15,16].

Some RIPs have also been found in edible plants (e.g., cereals, butternut squash (Cucurbita moschata) and bitter melon (Momordica charantia)) and are therefore eaten by humans [17-19], although their toxicity is reduced or eliminated during digestion or by cooking food at high temperatures. Nevertheless, some type 2 RIPs have been also identified as potential food allergens [19,20].

In this framework, we previously purified and enzymatically characterised a type 1 RIP (named quinoin) from the functional food Chenopodium quinoa Willd seeds [21], considering their beneficial action in relation to several human diseases, despite the presence of anti-nutritional factors [22]. Quinoin is a thermostable protein $\left(\mathrm{Tm}=68.2^{\circ} \mathrm{C}\right)$, is cytotoxic against BJ-5ta (human fibroblasts) and $\mathrm{HaCaT}$ (human keratinocytes) in a dose- and time-dependent manner and is partially resistant to an in vitro digestive pepsin-trypsin treatment [21]. Although several biochemical aspects of quinoin have been studied, some important questions remain unsolved such as the primary structure characterization and its possible antipathogenic activities.

Taking into account the above, the aim of the present study was: (i) obtain the primary structure of quinoin; (ii) analyse the gene structure of quinoin through a bioinformatics approach considering the genome availability of C. quinoa; and (iii) characterise its different activities against fungi, bacteria and plant viruses.

\section{Results}

\subsection{Protein Purification}

The homogenous preparation of quinoin for structural characterization and biological assays was achieved as previously reported [21]. Briefly, a quinoa seed extract was subjected to acid precipitation and soluble proteins were separated, exploiting both the differences in protein size (size exclusion chromatography) and the charge properties (cation exchange chromatography).

Moreover, from the last step of purification by CM-Sepharose chromatography in addition to the main protein peak (peak three), which corresponds to quinoin, two minor protein peaks (peak one and peak two) eluted at a lower ionic strength with respect to the quinoin peak, were identified (Figure S1a). The pooled fractions of peaks one and two were 
able to release the $\beta$-fragment diagnostic for RIPs action ( $\mathrm{N}$-glycosylase activity), shown in Figure 1a.
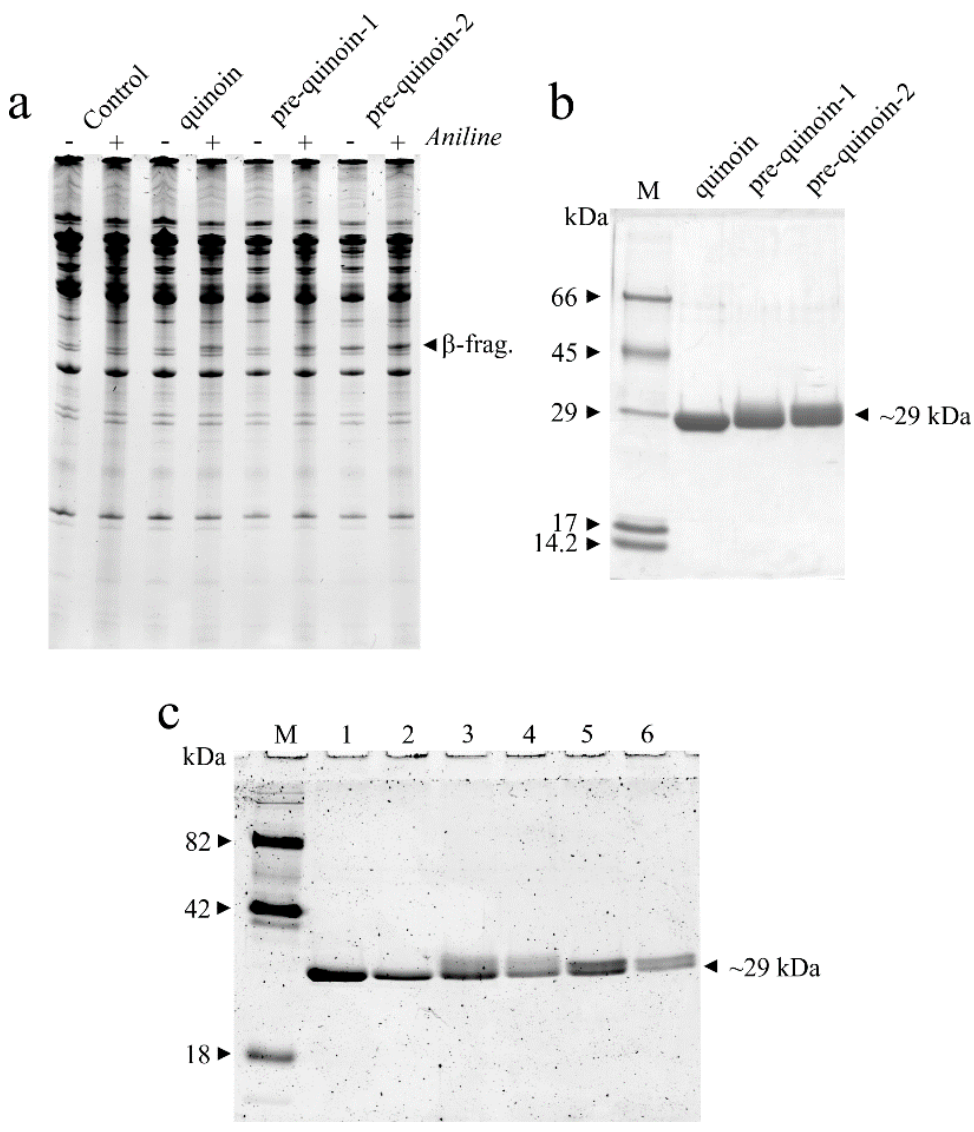

Figure 1. (a) rRNA N-glycosylase activity of quinoin, pre-quinoin-1 and pre-quinoin-2 on rabbit ribosomes. rRNA N-glycosylase activity was assayed as indicated in the 'Material and Methods' section. Each lane contained $3.0 \mu \mathrm{g}$ of RNA isolated from either untreated (control) or RIP treated ribosomes from a rabbit. $\beta$-frag. indicates the RNA fragment (Endo's fragment) released as a result of RIP action after acid aniline treatment (+); (-) without aniline treatment. (b) Analysis by SDS-PAGE of the three RIPs isolated from C. quinoa seeds. M, marker proteins. SDS-PAGE was carried out in $12 \%$ polyacrylamide separating gel under reducing conditions. (c) A total of 3.0 and $1.5 \mu \mathrm{g}$ of quinoin (lane 1 and 2, respectively), pre-quinoin-1 (lane 3 and 4, respectively) and pre-quinoin-2 (lane 5 and 6 , respectively) were run on $12 \%$ SDS-PAGE under reducing conditions, followed by in-gel glycan detection using the Pro-Q Emerald 300 glycoprotein staining kit. Stained proteins were visualised by UV trans-illumination. M, CandyCane ${ }^{\mathrm{TM}}$ glycoprotein molecular weight standards.

In this framework, to obtain a more homogeneous preparation of these novel RIPs, a further purification step by FPLC was carried out for both pools. The Source-S rechromatography profiles showed the presence of a main principal protein peak, hereafter named pre-quinoin-1 and pre-quinoin-2 (Figure S1b,c). The SDS-PAGE analysis showed that the fractions of pre-quinoin- 1 and pre-quinoin- 2 contained a single protein band, with a mobility for both corresponding to $\sim 30-\mathrm{kDa}$ (data not shown), for which these protein fractions contained two novel type 1 RIPs. Therefore, the fractions corresponding to prequinoin-1 and pre-quinoin- 2 were pooled, dialyzed against water and used for further experiments considering their homogeneity shown by the SDS-PAGE analysis (Figure 1b). The yield of the purified proteins pre-quinoin- 1 and pre-quinoin- 2 was $\sim 0.11 \mathrm{mg} / 100 \mathrm{~g}$ and $\sim 0.85 \mathrm{mg} / 100 \mathrm{~g}$ of seeds, respectively.

Finally, to investigate the possibility that the slight altered migration (smear) in the SDS-PAGE of pre-quinoin-1 and pre-quinoin-2 (see Figure 1b) could be due to glycosy- 
lation, a specific analysis for glycoproteins detection was carried out. When analysed by SDS-PAGE and sugar staining, the proteins appeared to be glycosylated (Figure 1c). In particular, glycosylation was more evident for pre-quinoin- 1 and pre-quinoin-2 with respect to quinoin, considering the very closed detected band of the latter.

\subsection{Determination of the Primary Structure of Quinoin}

The amino acid sequence of quinoin was obtained by using a strategy based on high-resolution nanoLC-Tandem Mass Spectrometry in order to quickly obtain information on the primary structure of the peptides obtained after tryptic and chymotryptic digestion. This information was then used as a query for mapping the proteins to the C. quinoa genome [23] by using the BLASTp algorithm (https://blast.ncbi.nlm. nih.gov; visit date 8 June 2021). Amino acid sequences of both the tryptic and chymotryptic peptides obtained by high-resolution tandem mass spectrometry are reported in Table 1. This survey revealed six proteins that were retrieved as 'protein synthesis inhibitor-like' that produced significant alignments. These sequences were: protein synthesis inhibitor PD-S2-like (A.C.: XP_021750597.1), ribosome-inactivating protein PDL3/PD-L4-like (A.C.: XP_021750694.1), protein synthesis inhibitor PD-S2-like_(2) (A.C.: XP_021737780.1), ribosome-inactivating protein PD-L3/PD-L4-like (A.C.: XP_021726635.1), antiviral protein MAP-like (A.C.: XP_021735486.1) and antiviral protein MAP-like (A.C.: XP_021750669.1). The amino acid sequences of these 'protein synthesis inhibitors like' are reported in Figure S2.

Table 1. Amino acid sequences of both tryptic (A) and chymotryptic (B) peptides from quinoin obtained by high-resolution nanoLC-Tandem Mass Spectrometry. Sequence, number of missed cleavages sites (MC), experimental masses of precursor ions, charge state and theoretical molecular weights of peptides $\left(\mathrm{MH}^{+}\right)$together with mass accuracies are reported.

\begin{tabular}{|c|c|c|c|c|c|c|c|}
\hline Sequence & MC & Charge & $m / z[\mathrm{Da}]$ & $\mathrm{MH}^{+}[\mathrm{Da}]$ & $\begin{array}{l}\Delta \text { mass } \\
{[\mathrm{ppm}]}\end{array}$ & $\begin{array}{l}\text { Sequence } \\
\text { Position }\end{array}$ & $\begin{array}{c}\text { Reported in } \\
\text { Figure } 2\end{array}$ \\
\hline \multicolumn{8}{|l|}{ A } \\
\hline [R].NDLYVVAFADK.[F] & - & 2 & 627.822 & 1254.636 & 0.45 & $72-82$ & $\mathrm{~T}_{\mathrm{MS} / \mathrm{MS}}-1$ \\
\hline [R].GHFFSNLNIDTIDK.[A] & - & 3 & 540.938 & 1620.801 & 0.59 & 89-102 & $\mathrm{T}_{\mathrm{MS} / \mathrm{MS}^{-}}-2$ \\
\hline [R].LSFPLGFDNLK.[T] & - & 2 & 625.842 & 1250.677 & 0.72 & 134-144 & $\mathrm{T}_{\mathrm{MS} / \mathrm{MS}^{-}} 3$ \\
\hline [K].VYGMDTK.[A] & - & 2 & 407.194 & 829.381 & 0.56 & $150-156$ & $\mathrm{~T}_{\mathrm{MS} / \mathrm{MS}^{-4}}$ \\
\hline [R].AIVTTNPNNYK.[I] & - & 2 & 617.824 & 1234.64 & 0.59 & 188-198 & $\mathrm{T}_{\mathrm{MS} / \mathrm{MS}^{-}}-5$ \\
\hline [K].ILSLENNWGAISK.[G] & - & 2 & 772.892 & 1444.78 & 1.01 & 199-211 & $\mathrm{T}_{\mathrm{MS} / \mathrm{MS}^{-6}}$ \\
\hline [K].NDMGLLK.[Y] & - & 2 & 395.710 & 790.412 & 0.44 & $245-251$ & $\mathrm{~T}_{\mathrm{MS} / \mathrm{MS}^{-7}}$ \\
\hline \multicolumn{8}{|l|}{ B } \\
\hline [K].LEPKPTQNTY.[N] & - & 2 & 595.806 & 1190.604 & 0.64 & $7-16$ & n.r. \\
\hline [K].LEPKPTQNTYNTF.[L] & Y16 & 2 & 776.885 & 1552.763 & 1.02 & $7-19$ & $\mathrm{Ch}_{\mathrm{MS} / \mathrm{MS}^{-1}}$ \\
\hline [K].DPSLVYEGIPM.[I] & - & 2 & 610.797 & 1220.586 & 0.73 & $29-39$ & $\mathrm{Ch}_{\mathrm{MS} / \mathrm{MS}^{-2}}$ \\
\hline [Y].LLVDLESK.[K] & - & 2 & 458.770 & 916.534 & 0.81 & $50-57$ & $\mathrm{Ch}_{\mathrm{MS} / \mathrm{MS}^{-3}}$ \\
\hline
\end{tabular}

"-", missed cleavage sites not retrieved; n.r., not reportedin Figure 2.

Among these, the protein synthesis inhibitor PD-S2-like (A.C.: XP_021750597.1) exhibited a closer identity with the sequences of both the tryptic and chymotryptic peptides derived from purified quinoin. In this framework, we decided to use the amino acid sequence of the protein synthesis inhibitor PD-S2-like (A.C.: XP_021750597.1) as a reference protein. The sequencing of both the obtained tryptic and chymotryptic peptides provided for $\sim 38 \%$ of the amino acid sequence of quinoin (106 out of 279 amino acid residues, referred to the protein synthesis inhibitor PD-S2-like sequence) and their overlap is reported in Figure 2a. Subsequently, for sequence completion and/or verification we decided to perform a comparative peptide mapping by MALDI-TOF mass spectrometry, using also in this case the primary structure of the protein synthesis inhibitor PD-S2-like (A.C.: XP_021750597.1) as a reference protein. To this aim, a new set of peptides derived from endoproteinase Arg-C, chymotrypsin and trypsin as well as the chemical fragmenta- 
tion $(\mathrm{CNBr})$ were analysed. The accurate $\mathrm{M} r$ of the peptides or fragments obtained from proteinase digestion and cyanogen bromide cleavage, respectively, were used to assemble the amino acid sequence of quinoin, as reported in Table 2, while the primary structure of quinoin with these overlapping peptides is reported in Figure 2a. In particular, the mapping of position 220-244 was achieved considering the Mr of two tryptic peptides T-6 and T-6' (experimental $\mathrm{Mr} 3490.28$ and 3636.56, respectively), the site of N-glycosylation (Asn231 in the NGT consensus sequence) and the reactivity of quinoin by the glycosylation analysis (see Figure 1c). Indeed, the analyses by the online Glycomod tool [24] allowed us to confirm that the Mrs of 3490.28 and 3636.56 were due to the theoretical molecular mass of the amino acid sequence 220-VINPALILQYPNGTTWTVTQVSDIK-244 (2772.19 Da) plus the molecular masses of the predicted glycan chains: [(Hex $)_{1}\left(\mathrm{HexNAc}_{2}(\text { Deoxyhexose })_{1}\right]$ $(714.67 \mathrm{Da})$ for T-6 and $\left[(\mathrm{Hex})_{2}(\mathrm{HexNAc})_{2}(\text { Pent })_{1}\right](862.79 \mathrm{Da})$ for T- $6^{\prime}$. In light of this, the theoretical Mrs of the glycosylated peptides T-6 and T- $6^{\prime}$ were 3487.87 ( $\Delta$ mass $=2.41$ with respect to the experimental $\mathrm{M} r$ ) and 3635.99 , respectively ( $\Delta$ mass $=0.57$ with respect to the experimental $\mathrm{Mr}$ ). These predicted possible oligosaccharide structures were retrieved in glycoproteins from plants, such as horseradish peroxidase $[25,26]$.

The strategy allowed the MS mapping of $\sim 99 \%$ of the quinoin sequence $(251 / 254$ amino acid residues) compared to the protein synthesis inhibitor PD-S2-like (A.C.: XP_021750597.1). Therefore, these data allowed us to confirm that the protein synthesis inhibitor PD-S2-like (A.C.: XP_021750597.1) amino acid sequence is the primary structure of quinoin. In addition, no sequence information was achieved for the $\mathrm{N}$-terminal peptide 'MQQENKKAWL VLTIAIWVVL QQVNA' (position -1 -25 in Figure 2a), for which it is most likely the N-terminal signal peptide of quinoin. This evidence was also obtained from the analysis of the protein synthesis inhibitor PD-S2-like amino acid sequence by the SignalP 5.0 server that predicts signal peptides sequences [27]. In particular, this tool predicted a theoretical specific cleavage site between Ala(-1) and Ala1 with a probability of 0.975 .

Table 2. Amino acid sequences and the molecular mass values of endoproteinase Arg-C (Arg-), chymotryptic (Ch-) and tryptic (T-) peptides as well as CNBr (CB-) fragments used to assemble the amino acid sequence of quinoin from Chenopodium quinoa.

\begin{tabular}{|c|c|c|c|c|c|c|}
\hline Peptide & $\begin{array}{l}\text { Sequence } \\
\text { Position }\end{array}$ & $\begin{array}{c}\text { Experimental } \\
\text { Molecular Mass }\end{array}$ & $\begin{array}{c}\text { Theoretical } \\
\text { Molecular Mass }\end{array}$ & $\Delta(\mathrm{Da})$ & $\begin{array}{c}\text { Missed } \\
\text { Cleavage at }\end{array}$ & $\begin{array}{c}\text { Reported in } \\
\text { Figure } 2\end{array}$ \\
\hline \multicolumn{7}{|c|}{ Arg-C peptides } \\
\hline 1 & $1-24$ & 2811.68 & 2811.47 & 0.21 & - & Arg-1 \\
\hline 2 & $25-41$ & 1934.75 & 1934.00 & 0.75 & - & Arg-2 \\
\hline \multicolumn{7}{|c|}{ chymotrypsin peptides } \\
\hline 1 & $40-49$ & 1173.57 & 1173.59 & 0.02 & - & Ch-1 \\
\hline 2 & $50-64$ & 1791.26 & 1790.99 & 0.27 & - & Ch-2 \\
\hline 3 & 84-91 & 857.48 & 857.47 & 0.01 & - & Ch-3 \\
\hline 4 & 93-103 & 2405.82 & 2405.31 & 0.51 & - & Ch-4 \\
\hline \multicolumn{7}{|c|}{ trypsin peptides } \\
\hline 1 & $59-71$ & 1505.68 & 1505.83 & 0.15 & K60 & $\mathrm{T}-1$ \\
\hline 2 & $72-86$ & 1643.64 & 1643.84 & 0.20 & K82 & $\mathrm{T}-2$ \\
\hline 3 & $103-133$ & 3489.78 & 3489.76 & 0.02 & K104, K105 & $\mathrm{T}-3$ \\
\hline 4 & $167-187$ & 2438.91 & 2438.37 & 0.54 & R181, K183 & $\mathrm{T}-4$ \\
\hline 5 & 199-219 & 2311.03 & 2311.32 & 0.29 & $\begin{array}{c}\text { K211, R214, } \\
\text { K218 }\end{array}$ & $\mathrm{T}-5$ \\
\hline 6 & $220-244$ & 3490.28 & $3487.87^{b}$ & 2.41 & - & $\mathrm{T}-6$ \\
\hline $6^{\prime}$ & $220-244$ & 3636.56 & $3635.99^{c}$ & 0.57 & - & $(\mathrm{T}-6)$ \\
\hline
\end{tabular}


Table 2. Cont.

\begin{tabular}{|c|c|c|c|c|c|c|}
\hline Peptide & $\begin{array}{l}\text { Sequence } \\
\text { Position }\end{array}$ & $\begin{array}{c}\text { Experimental } \\
\text { Molecular Mass }\end{array}$ & $\begin{array}{c}\text { Theoretical } \\
\text { Molecular Mass }\end{array}$ & $\Delta(\mathrm{Da})$ & $\begin{array}{c}\text { Missed } \\
\text { Cleavage at }\end{array}$ & $\begin{array}{l}\text { Reported in } \\
\text { Figure } 2\end{array}$ \\
\hline \multicolumn{7}{|c|}{ CNBr fragments } \\
\hline 1 & $148-153$ & 678.36 & $678.35^{d}$ & 0.01 & - & CB-1 \\
\hline 2 & $154-174$ & 2394.34 & $2394.30^{d}$ & 0.04 & - & CB-2 \\
\hline 3 & $248-254$ & 793.46 & $793.00^{\mathrm{d}}$ & 0.46 & - & CB-3 \\
\hline
\end{tabular}

a , the theoretical molecular masses were obtained from the protein synthesis inhibitor PD-S2-like (A.C.: XP_021750597.1) retrieved in the C. quinoa genome. ${ }^{b}$, the theoretical molecular mass was obtained considering the molecular masses of peptide (2772.19 Da) plus the glycan chain $\left[(\mathrm{Hex})_{1}(\mathrm{HexNAc})_{2}(\text { Deoxyhexose })_{1}\right](714.67 \mathrm{Da}) .{ }^{\mathrm{c}}$, the theoretical molecular mass was obtained considering the molecular masses of peptide $(2772.19 \mathrm{Da})$ plus glycan chain $\left[(\mathrm{Hex})_{2}(\mathrm{HexNAc})_{2}(\mathrm{Pent})_{1}\right](862.79 \mathrm{Da}){ }^{\mathrm{d}}$, $\left[\mathrm{M}+\mathrm{H}^{+}\right]^{+}$experimental molecular mass values obtained by MALDI-TOF MS. The monoisotopic molecular masses were considered. The theoretical molecular weight was obtained considering the presence at the C-terminal of homoserine lactone, except for CB-3 for which homoserine was considered. "-", missed cleavage sites not retrieved. $\Delta(\mathrm{Da})$, difference between theoretical and experimental molecular masses.

\section{a}

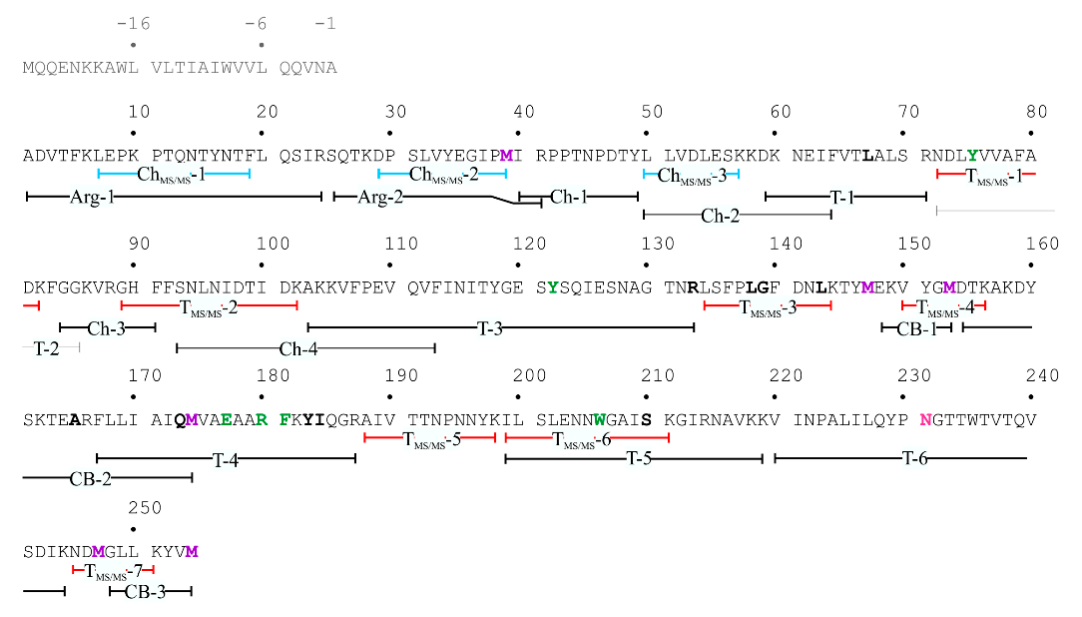

b

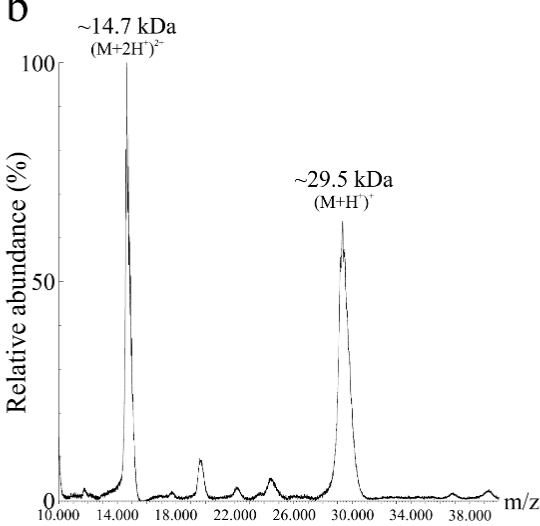

Figure 2. (a) Amino acid sequence of quinoin obtained using the protein synthesis inhibitor PD-S2like A.C.: XP_021750597.1 in the Chenopodium quinoa genome as a reference. The overlapping peptides used for assembling the purified protein sequence are reported. Amino acid residues located in the active site and those that might be in contact with the adenine substrate are highlighted in green or bold, respectively [6]. Methionyl residues and glycosylated asparaginyl residue are in magenta and pink, respectively. The $\mathrm{N}$-terminal signal peptide is reported in light grey (position $-25-1$ ). Abbreviations: $\mathrm{T}_{\mathrm{MS} / \mathrm{MS}}$ and $\mathrm{Ch}_{\mathrm{MS} / \mathrm{MS}}$, respectively, tryptic and chymotryptic peptides obtained by high-resolution tandem mass spectrometry. Arg-, Ch-, T- (endoproteinase Arg-C, chymotryptic and tryptic peptides, respectively) and CB (cyanogen bromide fragments) analysed by MALDI-TOF spectrometer. (b), MALDI-TOF mass spectrum of native quinoin. The peak at 14.7-kDa corresponds to the doubly charged ion $\left[\mathrm{M}+2 \mathrm{H}^{+}\right]^{2+}$. 
Finally, the quinoin sequence accounted for a calculated molecular mass of 28,766.1 Da, which was in agreement with the value obtained by MALDI-TOF mass spectrometry on the native protein ( $29.5 \mathrm{kDa}$; Figure $2 \mathrm{~b})$, taking into account the heterogeneity due to the presence of the glycan chains moiety on Asn231.

Overall, purified quinoin has 254 amino acid residues, one N-glycosylated asparaginyl residue and no cysteinyl residues.

\subsection{Sequence Comparison, Structural Features and Homology Model of Quinoin}

In order to obtain information regarding the identity/similarity of quinoin with other RIPs and to gain insight into its structural features, we performed a search for sequence homology. Among the numerous sequences showing a degree of identity, ranging from about $50 \%$ to about $30 \%$, we focused our interest on those reported in Table S1. In Figure S3, the quinoin sequence is aligned with those of a number of type 1 RIPs found in the Caryophyllales order (Phytolacca americana, Phytolacca dioica, Saponaria officinalis, Dianthus caryophyllus, Silene chalcedonica and Mirabilis jalapa) and two A-chain of type 2 RIPs found in Ricinus communis. The multiple alignment analysis showed that, in all the RIPs evaluated, the active site residues (Tyr75, Tyr122, Glu177, Arg180, Phe181 and Trp206; numbering refers to the quinoin amino acid sequence) involved in the enzymatic mechanism (Glu177 and Arg180) and in the binding with adenine (Tyr75, Tyr122, Phe181 and Trp206) were conserved [6]. Furthermore, considering the obtained logo from the alignment performed (Figure 3a), other amino acid residues were conserved (i.e., Leu67, Arg133, Leu138, Gly139, Leu143, Ala165, Gln173, Tyr183, Ile184 and Ser210 numbering refers to the quinoin amino acid sequence), which correspond to the positions 73,152 , 157, 158, 162, 185, 193, 203, 204 and 235 in the sequence logo. Although many of these residues do not participate directly in the catalytic site, they are important for the correct rearrangement of the fold of the RIPs, considering the organization necessary for the recognition of the target adenine (active-site cleft) in the SRL loop and to expand the network able to promote catalysis by the internal dynamics of these enzymes [6,28]. In particular, experimental data reported in the literature shows that: (i) Ser235 (Ser210 in quinoin) has an important role in stabilizing the conformation of Trp231 (Trp206 in quinoin) side chain through the formation of a specific hydrogen bond [29]; (ii) while Arg152 (Arg133 in quinoin) is an amino acid residue that participates in the binding to the SRL loop [30].

Phylogenetic relationships were investigated among the 21 RIPs sequences analysed by using the Maximum Likelihood method. The sequence of both ricin and agglutinin Achains, two ribosome-inactivating proteins from $R$. communis belonging to the Euphorbiales order, were used as an outgroup. Two main groups were highlighted by the analysis of the unrooted phylogenetic tree (Figure 3b). The first group (a) included quinoin, lychnin (S. chalcedonica), dianthin-30 (D. caryophyllus) and the saporins (S. officinalis), while all other RIPs (PAP-S, PD-L1/2, PD-L3/4, PD-S2, heterotepalin-4, PAP-I, PAP- $\alpha$, diocin-2 and PAPII) were located on a separate branch group (b) all belonging to the Phytolaccaceae family. These findings suggest that quinoin shares common ancestors with lychnin, dianthin-30 and saporins. It is interesting to note from a structural point of view that all the proteins that belonged to group (b) (Phytolaccaceae) had four cysteinyl residues, while quinoin and other members of group (a) were without cysteinyl residues (except for lychnin, two cysteinyl residues), as shown in Figure S3. This could indicate a different selection pressure and distinct functional roles in these plants. These divergent structural features between quinoin and type 1 RIPs were confirmed by testing the possible cross-reactivity between quinoin and several type 1 RIPs from $P$. dioica (PD-S2, type 1 RIPs from the seed of P. dioica [31]; PD-L1 and PD-L4, type 1 RIPs from the leaves of P. dioica [32]) using both anti-quinoin and anti-PD-S2 polyclonal rabbit antibodies, respectively. The western blot analysis reported in Figure S4 highlighted a very weak cross-reactivity among quinoin and PD-S2, PD-L1 and PD-L4, confirming the different structural properties that exist between quinoin and type 1 RIPs from Phytolaccaceae. 

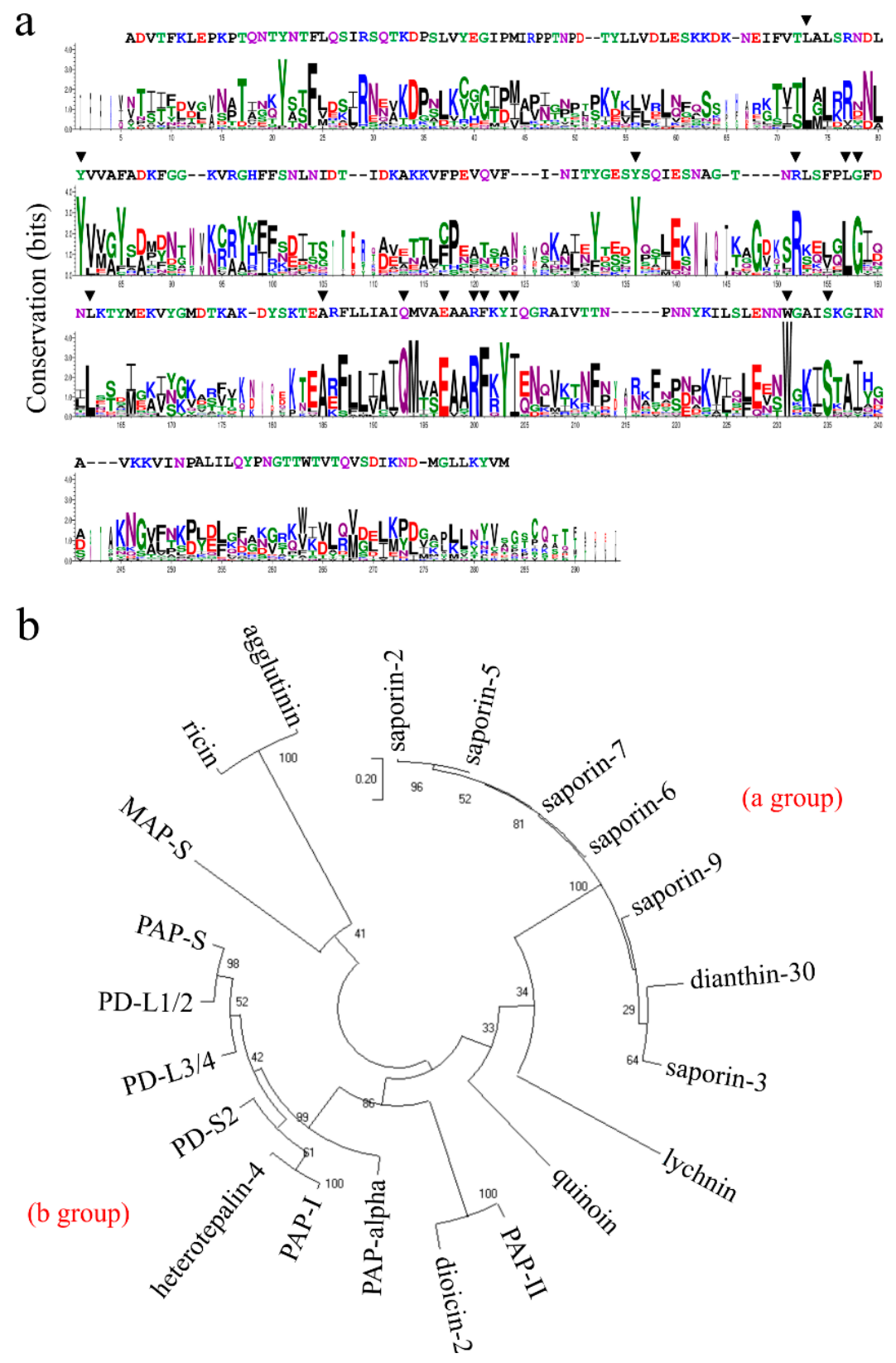

Figure 3. (a) Sequence logo between quinoin and ribosome-inactivating proteins. The sequence logo representation of the alignment of sequences (Figure S2) from 20 representative ribosome-inactivating proteins (Table S1) was created as indicated in the 'Material and Methods' section. Letter height is proportional to the conservation of that amino acid at that position in the alignment with respect to all the amino acids; letter width is proportional to the conservation of that amino acid but includes gaps. The colour of each amino acid is according to its chemical properties: polar (G, S, T, Y, C), green; neutral $(Q, N)$, purple; basic $(K, R, H)$, blue; acidic (D, E), red; hydrophobic (A, V, L, I, P, W, F, M), black. The sequence of quinoin is indicated above the logo. $\boldsymbol{\nabla}$ indicates the conserved amino acid residues in the alignment. (b) Molecular phylogenetic analysis by the Maximum Likelihood method of quinoin and 20 representative ribosome-inactivating proteins. The evolutionary history was inferred as indicated in the 'Material and Methods' section. The name of the ribosome-inactivating proteins is indicated, while the species and the accession numbers are reported in Table S1. All the sequences were retrieved and processed as indicated in the 'Material and Methods' section.

Finally, in order to carry out a predictive study of the structure of quinoin, we used the online I-TASSER service; the program built a three-dimensional model of quinoin by 
selecting (automatically) the three-dimensional structure of RIPs as a template. For quinoin, the computational modeling calculation generated a single conformer with a C-score of 1.09 indicating the good quality of the predicted three-dimensional structure. The overall fold of the quinoin model, including the secondary structure elements, is shown in Figure 4a. The three-dimensional structural model indicated that quinoin presents a typical 'RIP-fold' consisting of two major domains: an $\mathrm{N}$-terminal domain with $\beta$-strands and $\alpha$-helices and a C-terminal containing predominantly $\alpha$-helices [33]. Moreover, it is evident that the amino acid residues that make up the active site of quinoin are present in the same cleft (insert of Figure 4a).

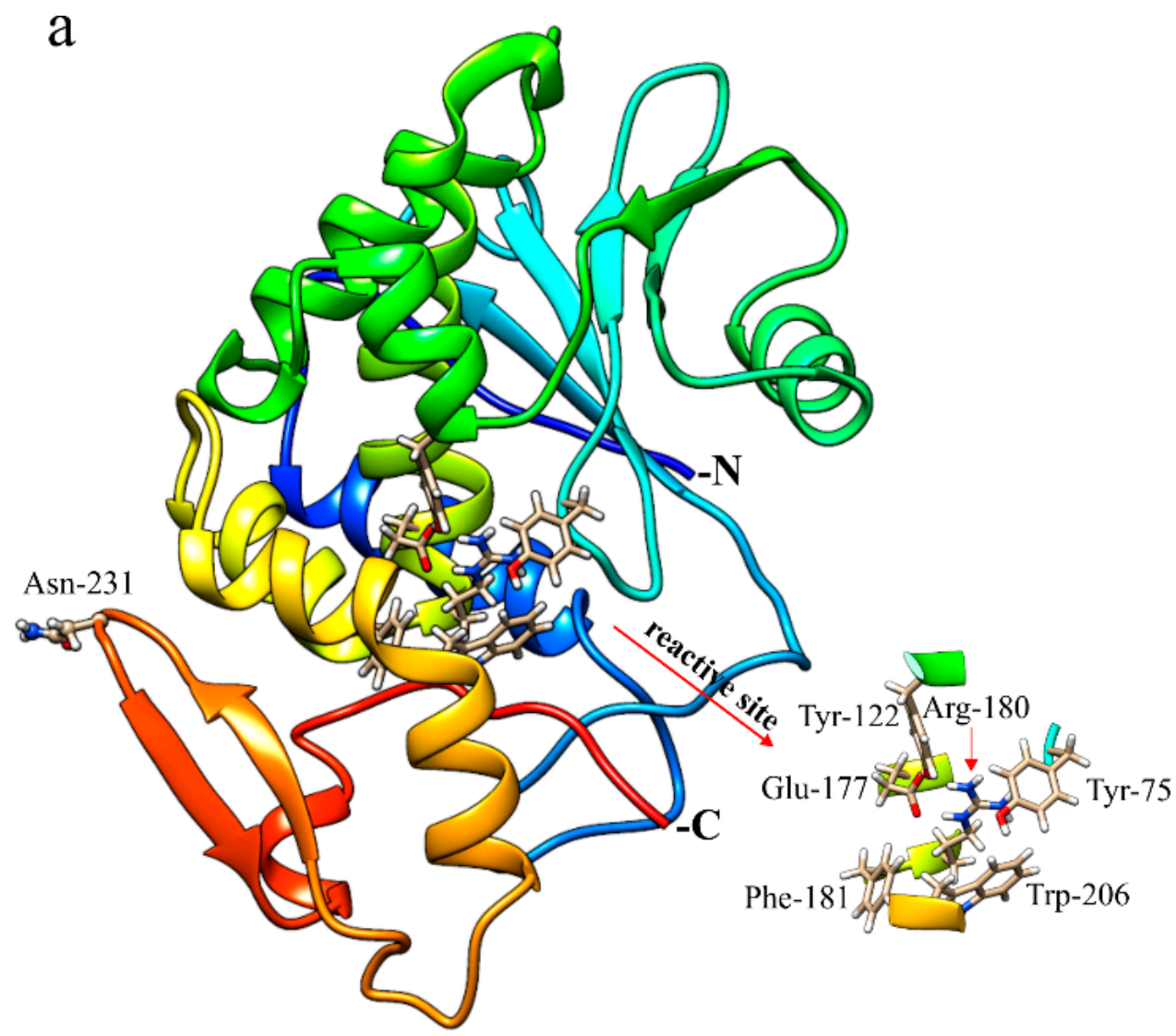

$\mathrm{b}$

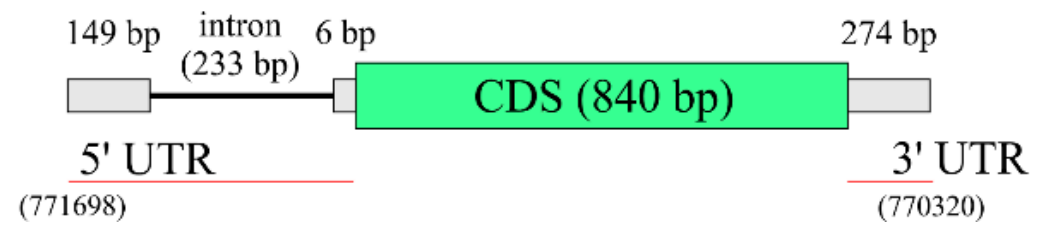

Figure 4. (a), Three-dimensional molecular model obtained for quinoin. In this model, reported as a backbone ribbon, the secondary structure topology is shown. $\mathrm{N}$ - and $\mathrm{C}$-, indicate $\mathrm{N}$ - and C-terminus amino acid residues of the protein, respectively. In the insert, we report the six amino acid residues present in the catalytic site, common to all RIPs [6]. (b) Schematic structure of the quinoin gene region with a single intron at $5^{\prime} \mathrm{UTR}$. This information is derived from the study on the NCBI reference sequence NW_018745569.1.

From the three-dimensional structural model of quinoin, the position of $\mathrm{N}$-glycosylated Asn231 was also investigated. This asparaginyl residue is part of an evident $\beta$-hairpin in 
the C-terminal region (position 225-237) that, as has been reported by many authors, plays a role in biological activity of RIPs. Indeed, several studies have reported that changes in this C-terminal region can alter: (i) the interaction with membrane models [34]; (ii) the RNA N-glycosylase activity and the adenines released from supercoiled DNA [35]; and (iii) the antiviral activity or some other biological action of these enzymes [36,37]. Considering as above, the $\mathrm{N}$-glycosylation of Asp231 could have a regulatory role in quinoin.

\subsection{Gene Organization of Quinoin}

The pioneering work of Stirpe et al. reported that the increase in the inhibitory activity of protein synthesis and activity on DNA is due to the presence of RIPs in the leaves of both Hura crepitans L. and P. americana when subjected to heat or osmotic stress [38]. Since then, experimental evidence has confirmed the control of the expression of RIPs at the gene level during abiotic and biotic stress in plants [39,40]. The de novo assembly of the pokeweed (P. americana) genome showed that the genes of both the pokeweed antiviral protein (PAP) and the PAP isoforms exhibited a long $5^{\prime}$ UTR containing one intron and cis-regulatory elements associated with diverse biotic and abiotic stresses [41].

In this framework, with information on the genome of C. quinoa, [23] and, in particular, on the genomic sequence coding for quinoin (A.C.: NW_018745569.1 in Gene Bank), we decided to investigate this region through a bioinformatics approach. The gene model coding for quinoin is shown in Figure $4 \mathrm{~b}$. The open reading frame (ORF) of quinoin was annotated as a single exon of $840 \mathrm{bp}$ (Figure S5), while the gene model revealed an intron within the $5^{\prime}$ UTR ( $\left.233 \mathrm{bp}\right)$. This model was similar to the gene models retrieved for the PAP isoforms. Therefore, the gene organization suggested that quinoin protein expression could be subjected to particular gene regulation in biotic and abiotic stresses given the presence of the $5^{\prime}$ UTR region of both the intron and the leader intron [41].

\subsection{Comparative MALDI-TOF Mass Spectrometry Mapping of Pre-Quinoin-1 and Pre-Quinoin-2}

In order to acquire the possible structural differences between quinoin and both pre-quinoin-1 and pre-quinoin-2 in addition to glycosylation, we decided to perform a comparative tryptic peptide mapping, using the quinoin primary structure as a reference peptide profile. Thus, the two proteins were first digested with trypsin and then the mixture of peptides was analysed by MALDI-TOF mass spectrometry.

The Mrs of the tryptic peptides retrieved for the digested pre-quinoin- 1 and prequinoin-2 forms are reported in Table 3 . A coverage of about $75 \%$ and $41 \%$ for pre-quinoin- 1 and pre-quinoin-2, respectively, was achieved considering the theoretical $\mathrm{Mr}$ of the tryptic peptides obtained from the amino acid sequence of quinoin.

Table 3. MALDI-TOF-MS analysis of the peptide mixtures obtained by the trypsin digest of prequenoin-1 and pre-quinoin-2. The theoretical molecular masses were obtained from the quinoin sequence (see Figure 2a).

\begin{tabular}{ccccccc}
\hline \multirow{2}{*}{$\begin{array}{c}\text { Theoretical } \\
\text { Molecular } \\
\text { Masses }\end{array}$} & \multirow{2}{*}{$\begin{array}{c}\text { Sequence } \\
\text { Position }\end{array}$} & \multicolumn{4}{c}{ Experimental Molecular Masses $^{\text {a }}$} & Missed \\
\cline { 3 - 6 } & Pre-Quinoin-1 & $\Delta(\mathrm{Da})$ & Pre-Quinoin-2 & $\Delta(\mathrm{Da})$ & Cleavage \\
\hline 790.41 & $245-251$ & 790.72 & 0.31 & 790.73 & 0.32 & - \\
\hline 813.64 & $150-156$ & 813.66 & 0.02 & 813.68 & 0.04 & - \\
\hline 1234.64 & $188-198$ & 1234.53 & 0.11 & 1234.58 & 0.06 & - \\
\hline 1250.67 & $134-144$ & 1250.56 & 0.11 & 1250.60 & 0.07 & - \\
\hline 1254.63 & $72-82$ & 1254.51 & 0.12 & 1254.58 & 0.05 & - \\
\hline 1444.77 & $199-211$ & 1444.45 & 0.32 & 1444.53 & 0.24 & - \\
\hline 1620.80 & $98-102$ & 1620.32 & 0.48 & 1620.28 & 0.52 & - \\
\hline 1643.84 & $72-86$ & 1643.33 & 0.51 & n.r. & & K82 \\
\hline
\end{tabular}


Table 3. Cont.

\begin{tabular}{ccccccc}
\hline \multirow{2}{*}{$\begin{array}{c}\text { Theoretical } \\
\text { Molecular } \\
\text { Masses }\end{array}$} & \multirow{2}{*}{$\begin{array}{c}\text { Sequence } \\
\text { Position }\end{array}$} & \multicolumn{3}{c}{ Experimental Molecular Masses ${ }^{\text {a }}$} & Missed \\
\cline { 3 - 6 } & & Pre-Quinoin-1 & $\Delta(\mathrm{Da})$ & Pre-Quinoin-2 & $\boldsymbol{\Delta ( D a )}$ & Cleavage \\
\hline 1664.80 & $145-158$ & 1664.30 & 0.50 & n.r. & K149, K156 \\
\hline 1819.93 & $89-104$ & 1819.31 & 0.62 & n.r. & K102 \\
\hline 2150.12 & $7-24$ & 2149.27 & 0.85 & 2149.31 & 0.81 & - \\
\hline 2278.27 & $163-182$ & 2277.31 & 0.96 & n.r. & n.r. & R166, R180 \\
\hline 2311.32 & $199-219$ & 2311.29 & 0.03 & K211, \\
\hline 2438.37 & $167-187$ & 2439.34 & 0.97 & 2439.11 & 0.74 & R180, K182 \\
\hline
\end{tabular}

n.r.: not retrieved. ${ }^{a}$, $\left[\mathrm{M}+\mathrm{H}^{+}\right]^{+}$experimental molecular mass values obtained by MALDI-TOF MS. The monoisotopic molecular masses have been considered. "-", missed cleavage sites not retrieved. $\Delta(\mathrm{Da})$, difference between theoretical and experimental molecular masses.

Therefore, taking into account the MALDI-TOF-MS peptide mapping, it is important to consider that both pre-quinoin-1 and pre-quinoin-2 type 1 RIPs are different glycosylated forms of quinoin, the major glycoform isolated from C. quinoa seeds. Moreover, a thorough analysis of the theoretical glycosylation sites in the quinoin primary structure revealed a second glycosylation site (Asn115 in the NIT consensus sequence), which could justify the presence of these glycoforms. This evidence is in agreement with the different glycosylated glycoforms of PD-S2, the major type 1 RIP characterised in the seeds of P. dioica [31].

\subsection{Antiviral Activity of Quinoin on TNV and TMV}

Several type 1 RIPs are known for their antiviral properties against many virus pathogens for plants, animals and bacteria. In light of this, several authors have proposed these enzymes as possible candidates to combat infectious diseases and, in particular, to control crop virus diseases, also considering the lack of specific antiviral products used in the open field [15].

Thus, we investigated the possible antiviral action of quinoin against TNV, which affects numerous cultivated plants. In a preliminary experiment, quinoin was tested at 2.0 and $10 \mu \mathrm{g} / \mathrm{mL}$ (70 and $350 \mathrm{nM}$ ), concentrations that had previously been shown to be effective in the case of PD-L1 and PD-L4, two type 1 RIPs from the leaves of P. dioica [16]. At both concentrations, quinoin completely abolished the TNV infection when inoculated together with the virus suspension in the same leaf surface (data not shown). On the basis of this result, quinoin was tested at 2.0 and $0.2 \mu \mathrm{g} / \mathrm{mL}(70$ and $7 \mathrm{nM}$ ) in three independent experiments which showed that the most diluted solution was able to greatly reduce the virus infection $(-96.88 \%$ ) when mixed with the virus inoculum (Figure 5a and Figure S6). Again, the concentration of $2.0 \mu \mathrm{g} / \mathrm{mL}$ almost completely abolished the infection as assessed by the very few and small lesions ( -99.99 total infected area) in respect to the plants inoculated only with the virus suspension in water (Figure 5a and Figure S6).

Interestingly, quinoin was able to inhibit the virus infection when it was also applied on the abaxial leaf surface separately from the TNV that was inoculated on the adaxial surface. In this case, the reduction in the necrotic lesions with $2.0 \mu \mathrm{g} / \mathrm{mL}$ of quinoin was still very high $(-94.72 \%)$ suggesting a synergistic action of this RIP against both viral and ribosomal RNA. Indeed, this evidence shows that there is no need for direct contact between virus and toxin; the virus inhibition would mainly occur inside the plant cells at the onset of infection [16]. In this framework, we investigated the potential effects of quinoin directly on the genomic RNA of TNV. As displayed in Figure 5b, quinoin promoted the in vitro depurination of the genomic RNA of TNV, which, upon treatment with acid aniline, led to the partial degradation of the polyphosphate RNA backbone (smear after aniline treatment). Finally, in order to confirm the in vitro depurination of the RNAs of the genomic virus plant, the same experiment was carried out on TMV genomic RNA, proving 
again the effect of quinoin against TMV RNA, as shown by gel electrophoresis (Figure 5c). Overall, these data highlight the depurination capacity of type 1 RIPs on genomic virus plant RNAs as previously reported for type 1 RIPs from P. dioica and Beta vulgaris L. [37,42].

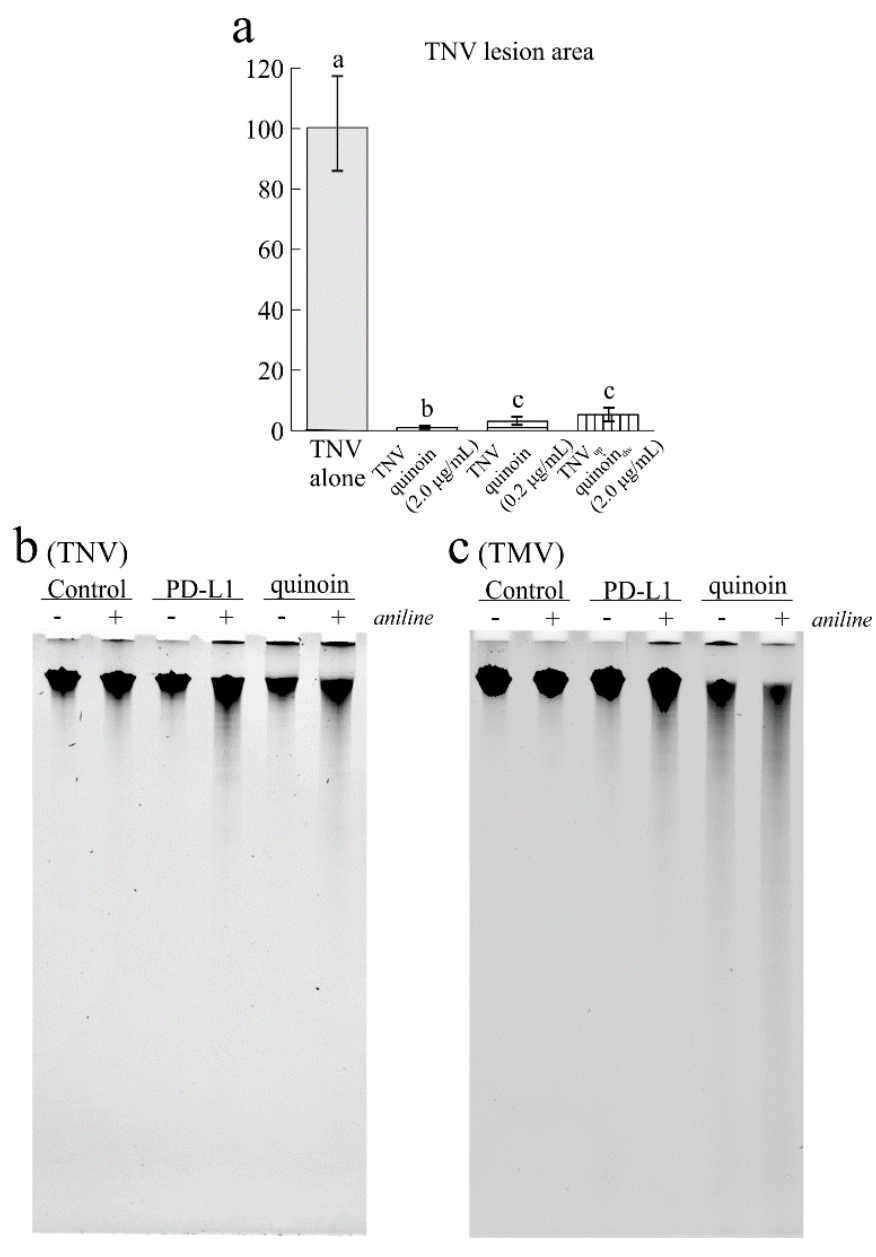

Figure 5. (a) The area of TNV lesions developed on bean cotyledonary leaves when the virus was inoculated alone or mixed with different concentrations of quinoin on the adaxial (up) leaf surface, or when inoculated separately from quinoin. The latter was applied on the abaxial leaf surface (down). Data are expressed as percentages of the total lesion area compared to the control (TNV alone) and refer to three independent experiments; different letters represent significant differences according to Fisher's least significant difference test at $p<0.05$; the same letter indicated no significant difference. $(\mathbf{b}, \mathbf{c})$ The adenine polynucleotide glycosylase activity of $3.0 \mu \mathrm{g}$ of quinoin, which was assayed on both TNV and TMV viral RNAs as indicated in the 'Material and Methods' section. Each lane contained $3.0 \mu \mathrm{g}$ of RNA. Samples were treated $(+)$ or not $(-)$ with acid aniline.

\subsection{Antimicrobial Activity}

RIPs are a class of defence proteins that could act as antimicrobial agents. Indeed, their antipathogenic activities have been reported against both bacteria and fungi, which makes them active subjects in plant defence $[11,17,43]$.

In light of this, we tested the antibacterial activity of quinoin towards some human and plant pathogenic bacteria. Quinoin showed a growth inhibition effect on the plant pathogens P. syringae pv. phaseolicola and P. syringae pv. actinidiae (Table 4). This activity was dose-dependent and showed the maximum inhibition at $100 \mu \mathrm{g} / \mathrm{mL}$. On the other hand, no effect was observed on the human pathogens S. aureus and S. enterica subsp. enterica serovar enteridis. 
Table 4. Antimicrobial activity of quinoin from the seeds of Chenopodium quinoa. The assays were carried out as reported in the 'Material and Methods' section and the values shown were obtained from three independent experiments.

\begin{tabular}{lccc}
\hline & \multicolumn{3}{c}{ Zone of Inhibition (mm \pm SD) } \\
\cline { 2 - 4 } Microbe & $\mathbf{3}$ Protein Amount \\
\cline { 2 - 4 } & $\mathbf{0 . 2} \boldsymbol{\mu g}$ & $\mathbf{0 . 5} \boldsymbol{\mu g}$ & $\mathbf{1 . 0} \boldsymbol{\mu g}$ \\
\hline Bacteria & $2.5 \pm 0.3$ & $3.4 \pm 0.5$ & $4.0 \pm 0.5$ \\
Pseudomonas syringae pv phaseolicola & $1.5 \pm 0.3$ & $1.8 \pm 0.3$ & $2.0 \pm 0.4$ \\
Pseudomonas syringae pv actinidiae & 0.0 & 0.0 & 0.0 \\
Salmonella enterica & 0.0 & 0.0 & 0.0 \\
Staphylococcus aureus & & & 0.0 \\
Fungi & 0.0 & 0.0 & 0.0 \\
Cryponectria parasitica strain E4 & 0.0 & 0.0 & \\
Cryponectria parasitica strain E13 & &
\end{tabular}

The antifungal activity of quinoin was tested on two strains of Cryphonectria parasitica, a parasitic fungus of chestnut trees. In this case, no inhibition halo was observed in either strain (Table 4) even though a slight effect on fungal growth was observed for both the C. parasitica strain E4 and strain E13 (Figure S7). In this framework, these data confirm that quinoin possesses antifungal activity although to a lesser extent, as reported for other RIPs against hyphomycete fungi such as Verticillium dahlia, Alternaria solani, Fusarium oxysporum solani [43-45] and other fungal genera [11].

\section{Discussion}

Quinoin is a type 1 RIP found in C. quinoa (quinoa) seeds and exhibits toxicity against different cell lines in vitro. In this framework, this toxin represents a possible anti-nutritional factor in quinoa seeds besides the presence of saponins, phytic acid, tannins, oxalates and trypsin inhibitors, commonly known as anti-nutritional factors [22]. Indeed, several studies have reported that some consumers are affected by innate immune responses or an insurgence of allergies or intolerances [46,47]. In this context, increased information on this type 1 RIP is of interest to verify the real impact of this toxin in a food that is highly requested today.

Thus, in this work, the amino acid sequence of quinoin was determined by using a combined approach based on C. quinoa genome analysis and mass spectrometry. This toxin is a glycoprotein and its polypeptide chain consists of 254 amino acid residues, without cysteinyl residues. Similarities in the protein database have been found with other known RIPs and a predictive three-dimensional structure model obtained by homology modeling showed a typical RIP-fold [33]. In addition, an identical spatial rearrangement of amino acid residues forming the active site pocket was retrieved [6]. Through a bioinformatics approach, it is interesting to note that the organization of the genomic sequence coding for quinoin showed a single exon containing ORF and an intron within the $5^{\prime}$ UTR. This organization is similar to the gene models retrieved for PAP isoforms, type 1 RIPs from P. americana, and seems to be necessary in gene regulation during biotic and abiotic stresses [41]. Moreover, two glycoproteins (electrophoretic migration of $\sim 30-\mathrm{kDa}$ ), able to release the $\beta$-fragment, named pre-quinoin- 1 and pre-quinoin-2, were purified and identified as different glycosylated forms of quinoin.

Finally, the antipathogenic activities of quinoin against several types of pathogens (fungi, bacteria and plant viruses) were evaluated. Quinoin possesses a strong antiviral activity towards TNV, even stronger than other previously tested RIPs. Interestingly, our data showed that this antiviral activity likely depends on both protein synthesis inhibition (N-glycosylase activity against ribosomes in cells) and depurination action on RNA virus genomes (activity verified in vitro on both TNV and TMV RNAs). In addition, this toxin showed a growth inhibitory effect on plant pathogen bacteria and a slight effect when tested against two C. parasitica strains. 
Overall, this investigation improves the knowledge of the structural features and the different antipathogenic activities of quinoin. In particular, the antipathogenic activities of this toxin could be used for tuning its possible use as a biotechnological tool.

\section{Materials and Methods}

\subsection{Materials}

Chemicals for protein purification chromatography were obtained as previously reported $[48,49]$. Other chemicals were from Merck Life Science (Milan, Italy). HPLC-grade solvents and reagents were obtained from VWR International (Milan, Italy). Cyanogen bromide was obtained from Fluka (Milan, Italy). Trypsin, chymotrypsin and endoproteinase Arg-C sequencing grades were obtained from Merck Life Science.

\subsection{Purification of Type 1 RIPs from the Seeds of C. quinoa}

Quinoin and minor forms of type 1 RIPs were purified according to the procedure published by Landi et al. (2021). In addition, for the purification of minority forms, after the last chromatography step on a CM-Sepharose column equilibrated in $5.0 \mathrm{mM}$ $\mathrm{Na}$ /phosphate, pH 7.2 (buffer A) and eluted in the same buffer with a $\mathrm{NaCl}$ (buffer B) gradient up to $0.15 \mathrm{M}$ (reservoir A, $500 \mathrm{~mL}$, reservoir B, $500 \mathrm{~mL}$; total volume $1 \mathrm{~L}$ ), a further purification step was introduced. In particular, the minor forms were re-chromatographed by FPLC on an AKTA Purifier System (Amersham Pharmacia; Milan, Italy), using a Source 15S PE 4.6/100 column, equilibrated in buffer A and eluted applying a linear gradient from 0 to $50 \%$ of buffer $\mathrm{A}$ containing $\mathrm{NaCl} 0.3 \mathrm{M}$ over $60 \mathrm{~min}$ (flow rate $1.0 \mathrm{~mL} / \mathrm{min}$ ).

\subsection{Enzymatic Assays}

The depurination assay (rRNA N-glycosylase assay) was conducted as previously described [37] on rabbit reticulocytes lysates as the substrate.

\subsection{Analytical Procedures}

Quinoin homogeneity was determined by SDS-PAGE with a Mini-Protean II (Bio-Rad; Milan, Italy) using a $6 \%$ stacking and $15 \%$ separating polyacrylamide gel under reducing conditions; a precision plus protein kit (Bio-Rad) was used as reference proteins. Protein concentration was determined by a Pierce BCA Protein Assay Kit (Life Technologies Italia Fil., Monza, Italy). Protein desalting was obtained by a reversed-phase HPLC (RP-HPLC) on a C-4 column $(4.6 \times 250 \mathrm{~mm}, 5.0-\mu \mathrm{m}$ particle size, $300 \AA$ A; Phenomenex, Castel Maggiore, Bologna, Italy) as previously reported [50]. The glycosylation analysis was performed in gel after SDS-PAGE by using the PRO-Q EMERALD 300 GLYCOPROT PROBES KOMBO (Life Technologies Italia). In other to investigate the cross-reactivity of RIPs, western blot protein samples were separated by 15\% SDS-PAGE and then transferred onto a PVDF membrane (Millipore Corp. for western blot) [48]. The primary polyclonal rabbit antibodies used (dilution 1:3000) were anti-quinoin or anti-PD-S2 (Bio-Fab research, Rome, Italy). Proteins were visualised by enhanced chemiluminescence (ECL, GE Healthcare, Chicago, IL, USA) using a ChemiDocTM XRS system and analysed by Quantity One software (date of use 12.6.2021; Bio-Rad, Milan, Italy).

\subsection{Digestion and Chemical Fragmentation of Quinoin}

The chemical fragmentation of quinoin $(50 \mu \mathrm{g})$ with cyanogen bromide (CNBr) was carried out in 70\% TFA as a solvent as previously described [50]. Enzymatic hydrolyses of quinoin $(50 \mu \mathrm{g})$ were achieved by dissolving the protein in $50 \mathrm{mM}\left(\mathrm{NH}_{4}\right) \mathrm{HCO}_{3}$ containing $10 \%$ acetonitrile. Subsequently, the protein was incubated with TPCK-treated trypsin, chymotrypsin or endoproteinase Arg-C with an enzyme/substrate 1:50 (w/w) final ratio added in three steps (the first at $0 \mathrm{~h}$ (E/S: 1:200); the second at $4 \mathrm{~h}(\mathrm{E} / \mathrm{S}: 1: 100)$ and the third at $12 \mathrm{~h}$ (overnight, E/S: 1:50); $16 \mathrm{~h}$ total). Mixtures were then incubated at $37^{\circ} \mathrm{C}$, acidified $(\mathrm{pH}<3.0)$ and frozen for subsequent analyses [50,51]. The Trypsin digestion of minor forms of RIPs isolated in C. quinoa seeds was carried out as reported above for quinoin. 


\subsection{High Resolution NanoLC-Tandem and MALDI-TOF MS Analyses}

Mass spectrometry analyses on quinoin tryptic or chymotryptic digests $(50 \mathrm{fmol})$ were performed on a Q-Exactive Orbitrap mass spectrometer equipped with an EASY-Spray nanoelectrospray ion source (Thermo Fisher Scientific, Bremen, Germany) and coupled to a Thermo Scientific Dionex UltiMate 3000RSLC nano-system (Thermo Fisher Scientific, Monza, Italy). The solvent composition was $0.1 \%$ formic acid (FA) in water (solvent A) and $0.1 \%$ FA in acetonitrile (solvent B). Peptides were loaded on a trapping PepMapTM100 $\mu$ Cartridge column C-18 (300- $\mu \mathrm{m} \times 0.5 \mathrm{~cm}, 5.0-\mu \mathrm{m}, 100 \AA)$ and desalted with solvent A for $3 \mathrm{~min}$ with at a flow rate of $10 \mu \mathrm{L} / \mathrm{min}$. After trapping, eluted peptides were separated on an EASY-Spray analytical column (50 cm $\times 75 \mu \mathrm{m}$ ID PepMap RSLC C-18, $3 \mu \mathrm{m}, 100 \AA$ A). The run condition involved heating to $35^{\circ} \mathrm{C}$ and a flow rate of $300 \mathrm{~nL} / \mathrm{min}$. The gradient for the peptides separation was $4 \%$ B for $3 \mathrm{~min}$, from 4 to $55 \%$ B in $60 \mathrm{~min}$, from 55 to $70 \% \mathrm{~B}$ in $10 \mathrm{~min}$, and from 70 to $95 \% \mathrm{~B}$ in $2 \mathrm{~min}$. Eluting peptides were analysed on the Q-Exactive mass spectrometer operating in positive polarity mode set-up as reported in previous works [52].

The relative molecular mass $(\mathrm{Mr} r)$ of desalted quinoin together with the peptides from the enzymatic and chemical hydrolyses were determined by using a MALDI-TOF mass spectrometer (Waters Micromass Co., Manchester, UK) as previously reported [51,52].

The Glycomod tool was used to predict theoretical glycosidic chains (https:/ / web. expasy.org/glycomod/; visit date 8 June 2021).

\subsection{Sequence Analysis and Homology Modeling}

RIPs similar to quinoin were obtained from the Uniprot database (http://www. uniprot.org/; visit date 8 June 2021) by using BLAST (https:/ / www.uniprot.org/blast/; visit date 8 June 2021). Only reviewed sequences (records manually annotated and with information extracted from the literature and curator-evaluated computational analysis) were used for subsequent analyses. The signal peptide, connecting peptide and processed peptide sequences were removed in order to use only mature protein sequences. The sequence alignment was performed using the ClustalW tool available online (https:/ / embnet.vital-it.ch/software/ClustalW.html; visit date 8 June 2021). The similarity/identity matrix was obtained using the Sequence Identity and Similarity (SIAS) tool (http:/ /imed. med.ucm.es/Tools/sias.html; visit date 8 June 2021). The sequence logo was obtained using WebLogo tool available online (https: / / weblogo.berkeley.edu; visit date 8 June 2021). The evolutionary history was performed by using MEGA 10.0.5 (Molecular Evolutionary Genetics Analysis; https:/ /www.megasoftware.net/ (visit date 8 June 2021) [53]. For this procedure, the Maximum Likelihood method based on the JTT matrix-based model option was used. Phylogeny was tested by 1000 bootstrap replications.

A model of the three-dimensional structure of quinoin was obtained using the automated I-TASSER service available at the site https:/ / zhanglab.ccmb.med.umich.edu/ I-TASSER/ (visit date 8 June 2021). The selection of templates was performed by using the I-TASSER that at first identifies structure templates by LOMETS from the PDB library. The online procedure yielded the three-dimensional model on the basis of the multiple-threading alignments by LOMETS and the iterative TASSER simulations [54]. The predicted three-dimensional structure of the protein was visualised and analysed using the software Chimera [55].

The study of the genomic sequence of the quinoin gene was performed by using the tools available on GenBank (https://www.ncbi.nlm.nih.gov/genbank/; visit date 8 June 2021). The genomic sequence for NW_018745569.1 was obtained from C. quinoa cultivar QQ74.

\subsection{Plant Material and Viruses for Bioassays}

Nicotiana tabacum, cv. White Burley, N. benthamiana and Phaseolus vulgaris, cv. Borlotto Nano Lingua di Fuoco, grown in a greenhouse at $24 \pm 2{ }^{\circ} \mathrm{C}$, RH $60 \pm 5 \%, 16 \mathrm{~h} / 8 \mathrm{~h}$ light/dark period, were used in this study. 
The Tobacco Mosaic Virus (TMV) was propagated in N. tabacum and purified from these plants following the Gooding and Hebert protocol [56]. The Tobacco Necrosis Virus (TNV) was propagated on N. benthamiana and purified from the systemic infected plants following Montalbini and Polverari protocol [57].

\subsection{Evaluation of the Antiviral Activity of Quinoin In Vivo on TNV}

Fully expanded cotyledonary leaves of P. vulgaris, cv. Borlotto Nano Lingua di Fuoco, were inoculated on the adaxial surface by rubbing them with a mixture of quinoin at different concentrations (10 to $0.2 \mu \mathrm{g} / \mathrm{mL}$ ) and purified TNV (1:1), using a 600-mesh carborundum as an abrasive. The final virus concentration in the inoculum was $100 \mathrm{ng} / \mathrm{mL}$. In some other experiments, quinoin was applied on the abaxial leaf surface while the virus was inoculated on the adaxial one in order to avoid contact between them. As controls, some plants were inoculated respectively with TNV alone, or with quinoin at different concentrations or water. Plants were observed for the development of lesions for up to 5 days. When the lesions were fully developed, the infected leaves were detached and immediately scanned at a 300 DPI resolution. Images were analysed with Global Lab (Data Translation, Norton, MA, USA) to determine the necrotic lesion area. The quinoin inhibitory activity was calculated as a percentage of the reduction in this area in respect to the leaves only inoculated with TNV. In total, 24 leaves from three independent experiments were analysed for each treatment.

\subsection{Adenine Polynucleotide Glycosylase Activity of Quinoin on the RNA of TNV and TMV In Vitro}

The N-glycosylase activity of RIPs was assayed in $100 \mu \mathrm{L}$ samples containing $5.0 \mu \mathrm{g}$ of TNV or TMV RNA, which were incubated with $3.0 \mu \mathrm{g}$ of quinoin for $1 \mathrm{~h}$ at $37^{\circ} \mathrm{C}$. After treatment, the RNA was analysed by phenolization, treated with $1.0 \mathrm{M}$ aniline acetate ( $\mathrm{pH} 4.5)$, precipitated with ethanol and separated by gel electrophoresis (15 $\mathrm{mA}$ for $1 \mathrm{~h}$ ) and visualised by ethidium bromide staining [37].

\subsection{Evaluation of the Antibacterial Activity of Quinoin}

The agar diffusion assay was carried out using two different human pathogenic species of Gram-negative and positive bacterial strains and two Gram-plant pathogenic strains. Gram-negative Salmonella enterica subsp. enterica serovar enteridis ATCC 13,076 and Gram-positive Staphylococcus aureus, Pseudomonas syringae pv. phaseolicola and Pseudomonas syringae pv. actinidiae. A single colony of each strain was inoculated with $10 \mathrm{~mL}$ of Luria Broth (LB, Merck, Darmstadt, Germany) and incubated overnight at 37 and $30{ }^{\circ} \mathrm{C}$ for human and plant pathogens, respectively. A total of $100 \mu \mathrm{L}$ of the bacterial culture was spread over LB agar plates. To check the antimicrobial activity of quinoin, $10 \mu \mathrm{L}$ of the different diluted solution $(20,50$ and $100 \mu \mathrm{g} / \mathrm{mL}$ ) were loaded on to $4 \mathrm{~mm}$ filter paper discs and placed on the inoculated plates. For reference, $10 \mu \mathrm{L}$ of MilliQ water was added on the paper dish in the same inoculated plates. Plates were incubated for $18 \mathrm{~h}$ at 37 and $30^{\circ} \mathrm{C}$ for human and plant pathogens, respectively. The inhibition zone was visualised by crystal violet staining as previously described [58], with some modifications. The area with no growth of bacteria around the dish was measured using a ruler.

\subsection{Evaluation of the Antifungal Activity of Quinoin}

The antifungal activity of quinoin was evaluated from two Cryphonectria parasitica strains (E4 and E13) deposited in the collection of the Agri-food and Environmental Microbiology Platform (PiMiAA), University of Brescia, Italy. The radial growth inhibition assay was carried out as previously described [43]. Briefly, a mycelium plug was placed in the centre of a Potato Dextrose Agar plate and a dish with different amounts of quinoin $(0.4,0.8$ and $2.1 \mathrm{mg} / \mathrm{mL})$ or water at the border. Antifungal activity was observed as a crescent-shaped zone of inhibition at the mycelial front. The effect on fungal growth was expressed qualitatively, according to the procedure of Schlumbaum et al. (1986) [59]. 
Supplementary Materials: The following are available online at https://www.mdpi.com/article/10 $.3390 /$ ijms22168964/s1.

Author Contributions: S.R., N.L. and A.C. (Angela Clemente) performed the molecular studies and the purification of the proteins; R.R., M.V. and A.C. (Angela Chambery) performed the mass spectrometry analyses; D.B. and E.G. performed antimicrobial activities; F.F. performed the antiviral activity; A.D.M. conceived the study, performed the experimental analyses, acquired the funding and wrote the paper. All authors have read and agreed to the published version of the manuscript.

Funding: This research was funded by V:ALERE (VAnviteLli pEr la RicErca) program, investments for research and young people of University of Campania 'Luigi Vanvitelli'.

Institutional Review Board Statement: Not applicable.

Informed Consent Statement: Not applicable.

Data Availability Statement: Raw data can be provided by the corresponding author on request.

Acknowledgments: This study was made possible by the care and abnegation of all participants, despite the absence of dedicated funds and chronic difficulties afflicting the Italian scientific community.

Conflicts of Interest: The authors have no conflict of interest to declare. The funders had no role in the design of the study; in the collection, analyses, or interpretation of data; in the writing of the manuscript, or in the decision to publish the results.

\section{References}

1. Stirpe, F. Ribosome-inactivating proteins: From toxins to useful proteins. Toxicon 2013, 67, 12-16. [CrossRef]

2. Shi, X.; Khade, P.K.; Sanbonmatsu, K.Y.; Joseph, S. Functional role of the sarcin-ricin loop of the $23 \mathrm{~S}$ rRNA in the elongation cycle of protein synthesis. J. Mol. Biol. 2012, 419, 125-138. [CrossRef]

3. Endo, Y.; Tsurugi, K. The RNA N-glycosidase activity of ricin A-chain. The characteristics of the enzymatic activity of ricin A-chain with ribosomes and with rRNA. J. Biol. Chem. 1988, 263, 8735-8739. [CrossRef]

4. De Virgilio, M.; Lombardi, A.; Caliandro, R.; Fabbrini, M.S. Ribosome-inactivating proteins: From plant defense to tumor attack. Toxins 2010, 2, 2699-2737. [CrossRef]

5. Bolognesi, A.; Polito, L.; Lubelli, C.; Barbieri, L.; Parente, A.; Stirpe, F. Ribosome-inactivating and adenine polynucleotide glycosylase activities in Mirabilis jalapa L. tissues. J. Biol. Chem. 2002, 277, 13709-13716. [CrossRef]

6. Di Maro, A.; Citores, L.; Russo, R.; Iglesias, R.; Ferreras, J.M. Sequence comparison and phylogenetic analysis by the Maximum Likelihood method of ribosome-inactivating proteins from angiosperms. Plant Mol. Biol. 2014, 85, 575-588. [CrossRef] [PubMed]

7. Wong, J.H.; Bao, H.; Ng, T.B.; Chan, H.H.L.; Ng, C.C.W.; Man, G.C.W.; Wang, H.; Guan, S.; Zhao, S.; Fang, E.F.; et al. New ribosome-inactivating proteins and other proteins with protein synthesis-inhibiting activities. Appl. Microbiol. Biotechnol. 2020, 104, 4211-4226. [CrossRef]

8. Lapadula, W.J.; Mascotti, M.L.; Juri Ayub, M. Whitefly genomes contain ribotoxin coding genes acquired from plants. Sci. Rep. 2020, 10, 15503. [CrossRef] [PubMed]

9. Liu, Y.; Tian, S.; Thaker, H.; Dong, M. Shiga Toxins: An Update on Host Factors and Biomedical Applications. Toxins 2021, 13, 222. [CrossRef] [PubMed]

10. Barbieri, L.; Battelli, M.G.; Stirpe, F. Ribosome-inactivating proteins from plants. Biochim. Biophys. Acta 1993, 1154, $237-282$. [CrossRef]

11. Zhu, F.; Zhou, Y.-K.; Ji, Z.-L.; Chen, X.-R. The Plant Ribosome-Inactivating Proteins Play Important Roles in Defense against Pathogens and Insect Pest Attacks. Front. Plant Sci. 2018, 9, 146. [CrossRef]

12. Stirpe, F.; Gilabert-Oriol, R. Ribosome-Inactivating Proteins: An Overview. In Plant Toxins; Carlini, C.R., Ligabue-Braun, R., Eds.; Springer: Dordrecht, The Netherlands, 2017; pp. 153-182.

13. Pizzo, E.; Di Maro, A. A new age for biomedical applications of Ribosome Inactivating Proteins (RIPs): From bioconjugate to nanoconstructs. J. Biomed. Sci. 2016, 23, 54. [CrossRef] [PubMed]

14. Akkouh, O.; Ng, T.B.; Cheung, R.C.; Wong, J.H.; Pan, W.; Ng, C.C.; Sha, O.; Shaw, P.C.; Chan, W.Y. Biological activities of ribosomeinactivating proteins and their possible applications as antimicrobial, anticancer, and anti-pest agents and in neuroscience research. Appl. Microbiol. Biotechnol. 2015, 99, 9847-9863. [CrossRef]

15. Citores, L.; Iglesias, R.; Ferreras, J.M. Antiviral Activity of Ribosome-Inactivating Proteins. Toxins 2021, 13, 80. [CrossRef]

16. Bulgari, D.; Landi, N.; Ragucci, S.; Faoro, F.; Di Maro, A. Antiviral Activity of PD-L1 and PD-L4, Type 1 Ribosome Inactivating Proteins from Leaves of Phytolacca dioica L. in the Pathosystem Phaseolus vulgaris-Tobacco Necrosis Virus (TNV). Toxins 2020, 12, 524. [CrossRef]

17. Barbieri, L.; Polito, L.; Bolognesi, A.; Ciani, M.; Pelosi, E.; Farini, V.; Jha, A.K.; Sharma, N.; Vivanco, J.M.; Chambery, A.; et al. Ribosome-inactivating proteins in edible plants and purification and characterization of a new ribosome-inactivating protein from Cucurbita moschata. Biochim. Biophys. Acta 2006, 1760, 783-792. [CrossRef] [PubMed] 
18. De Zaeytijd, J.; Van Damme, E.J. Extensive Evolution of Cereal Ribosome-Inactivating Proteins Translates into Unique Structural Features, Activation Mechanisms, and Physiological Roles. Toxins 2017, 9, 123. [CrossRef]

19. Chen, Y.J.; Zhu, J.Q.; Fu, X.Q.; Su, T.; Li, T.; Guo, H.; Zhu, P.L.; Lee, S.K.; Yu, H.; Tse, A.K.; et al. Ribosome-Inactivating Protein $\alpha$-Momorcharin Derived from Edible Plant Momordica charantia Induces Inflammatory Responses by Activating the NF-kappaB and JNK Pathways. Toxins 2019, 11, 694. [CrossRef] [PubMed]

20. Barre, A.; Damme, E.; Simplicien, M.; Benoist, H.; Rougé, P. Are Dietary Lectins Relevant Allergens in Plant Food Allergy? Foods 2020, 9, 1724. [CrossRef]

21. Landi, N.; Ruocco, M.R.; Ragucci, S.; Aliotta, F.; Nasso, R.; Pedone, P.V.; Di Maro, A. Quinoa as source of type 1 ribosome inactivating proteins: A novel knowledge for a revision of its consumption. Food Chem. 2021, 342, 128337. [CrossRef]

22. Filho, A.M.; Pirozi, M.R.; Borges, J.T.; Pinheiro Sant'Ana, H.M.; Chaves, J.B.; Coimbra, J.S. Quinoa: Nutritional, functional, and antinutritional aspects. Crit. Rev. Food Sci. Nutr. 2017, 57, 1618-1630. [CrossRef] [PubMed]

23. Jarvis, D.E.; Ho, Y.S.; Lightfoot, D.J.; Schmöckel, S.M.; Li, B.; Borm, T.J.A.; Ohyanagi, H.; Mineta, K.; Michell, C.T.; Saber, N.; et al. The genome of Chenopodium quinoa. Nature 2017, 542, 307-312. [CrossRef]

24. Cooper, C.A.; Gasteiger, E.; Packer, N.H. GlycoMod -a software tool for determining glycosylation compositions from mass spectrometric data. Proteomics 2001, 1, 340-349. [CrossRef]

25. Takahashi, N.; Lee, K.B.; Nakagawa, H.; Tsukamoto, Y.; Masuda, K.; Lee, Y.C. New N-glycans in horseradish peroxidase. Anal. Biochem. 1998, 255, 183-187. [CrossRef] [PubMed]

26. Wilson, I.B.; Zeleny, R.; Kolarich, D.; Staudacher, E.; Stroop, C.J.; Kamerling, J.P.; Altmann, F. Analysis of Asn-linked glycans from vegetable foodstuffs: Widespread occurrence of Lewis a, core alpha1,3-linked fucose and xylose substitutions. Glycobiology 2001, 11, 261-274. [CrossRef]

27. Almagro Armenteros, J.J.; Tsirigos, K.D.; Sønderby, C.K.; Petersen, T.N.; Winther, O.; Brunak, S.; von Heijne, G.; Nielsen, H SignalP 5.0 improves signal peptide predictions using deep neural networks. Nat. Biotechnol. 2019, 37, 420-423. [CrossRef] [PubMed]

28. Agarwal, P.K. Enzymes: An integrated view of structure, dynamics and function. Microb. Cell Fact. 2006, 5, 2. [CrossRef] [PubMed]

29. Chambery, A.; Pisante, M.; Di Maro, A.; Di Zazzo, E.; Ruvo, M.; Costantini, S.; Colonna, G.; Parente, A. Invariant Ser211 is involved in the catalysis of PD-L4, type I RIP from Phytolacca dioica leaves. Proteins 2007, 67, 209-218. [CrossRef]

30. Li, X.P.; Kahn, P.C.; Kahn, J.N.; Grela, P.; Tumer, N.E. Arginine residues on the opposite side of the active site stimulate the catalysis of ribosome depurination by ricin A chain by interacting with the P-protein stalk. J. Biol. Chem. 2013, 288, 30270-30284. [CrossRef]

31. Chambery, A.; Di Maro, A.; Parente, A. Primary structure and glycan moiety characterization of PD-Ss, type 1 ribosomeinactivating proteins from Phytolacca dioica L. seeds, by precursor ion discovery on a Q-TOF mass spectrometer. Phytochemistry 2008, 69, 1973-1982. [CrossRef]

32. Di Maro, A.; Valbonesi, P.; Bolognesi, A.; Stirpe, F.; De Luca, P.; Siniscalco Gigliano, G.; Gaudio, L.; Delli Bovi, P.; Ferranti, P.; Malorni, A.; et al. Isolation and characterization of four type-1 ribosome-inactivating proteins, with polynucleotide:adenosine glycosidase activity, from leaves of Phytolacca dioica L. Planta 1999, 208, 125-131. [CrossRef] [PubMed]

33. Robertus, J.D.; Monzingo, A.F. The structure of ribosome inactivating proteins. Mini Rev. Med. Chem. 2004, 4, 477-486. [CrossRef]

34. Reyes, L.F.; Nobre, T.M.; Pavinatto, F.J.; Zaniquelli, M.E.; Caseli, L.; Oliveira, O.N., Jr.; Araújo, A.P. The role of the C-terminal region of pulchellin A-chain in the interaction with membrane model systems. Biochim. Biophys. Acta 2012, 1818, 82-89. [CrossRef]

35. He, W.J.; Liu, W.Y. Both N- and C-terminal regions are essential for cinnamomin A-chain to deadenylate ribosomal RNA and supercoiled double-stranded DNA. Biochem. J. 2004, 377, 17-23. [CrossRef] [PubMed]

36. Baykal, U.; Tumer, N.E. The C-terminus of pokeweed antiviral protein has distinct roles in transport to the cytosol, ribosome depurination and cytotoxicity. Plant J. 2007, 49, 995-1007. [CrossRef] [PubMed]

37. Iglesias, R.; Citores, L.; Ragucci, S.; Russo, R.; Di Maro, A.; Ferreras, J.M. Biological and antipathogenic activities of ribosomeinactivating proteins from Phytolacca dioica L. Biochim. Biophys. Acta 2016, 1860, 1256-1264. [CrossRef]

38. Stirpe, F.; Barbieri, L.; Gorini, P.; Valbonesi, P.; Bolognesi, A.; Polito, L. Activities associated with the presence of ribosomeinactivating proteins increase in senescent and stressed leaves. FEBS Lett. 1996, 382, 309-312. [CrossRef]

39. Wytynck, P.; Lambin, J.; Chen, S.; Demirel Asci, S.; Verbeke, I.; De Zaeytijd, J.; Subramanyam, K.; Van Damme, E.J.M. Effect of RIP Overexpression on Abiotic Stress Tolerance and Development of Rice. Int. J. Mol. Sci. 2021, 22, 1434. [CrossRef]

40. Polito, L.; Bortolotti, M.; Mercatelli, D.; Mancuso, R.; Baruzzi, G.; Faedi, W.; Bolognesi, A. Protein synthesis inhibition activity by strawberry tissue protein extracts during plant life cycle and under biotic and abiotic stresses. Int. J. Mol. Sci. 2013, 14, 15532-15545. [CrossRef] [PubMed]

41. Neller, K.C.M.; Diaz, C.A.; Platts, A.E.; Hudak, K.A. De novo Assembly of the Pokeweed Genome Provides Insight into Pokeweed Antiviral Protein (PAP) Gene Expression. Front. Plant Sci. 2019, 10, 1002. [CrossRef]

42. Barbieri, L.; Valbonesi, P.; Gorini, P.; Pession, A.; Stirpe, F. Polynucleotide: Adenosine glycosidase activity of saporin-L1: Effect on DNA, RNA and poly(A). Biochem. J. 1996, 319, 507-513. [CrossRef]

43. Vivanco, J.M.; Savary, B.J.; Flores, H.E. Characterization of two novel type I ribosome-inactivating proteins from the storage roots of the andean crop Mirabilis expansa. Plant Physiol. 1999, 119, 1447-1456. [CrossRef] 
44. Sharma, N.; Park, S.W.; Vepachedu, R.; Barbieri, L.; Ciani, M.; Stirpe, F.; Savary, B.J.; Vivanco, J.M. Isolation and characterization of an RIP (ribosome-inactivating protein)-like protein from tobacco with dual enzymatic activity. Plant Physiol. 2004, 134, 171-181. [CrossRef] [PubMed]

45. Rezaei-Moshaei, M.; Dehestani, A.; Bandehagh, A.; Pakdin-Parizi, A.; Golkar, M.; Heidari-Japelaghi, R. Recombinant pebulin protein, a type 2 ribosome-inactivating protein isolated from dwarf elder (Sambucus ebulus L.) shows anticancer and antifungal activities in vitro. Int. J. Biol. Macromol. 2021, 174, 352-361. [CrossRef]

46. Aurich, S.; Simon, J.C.; Treudler, R. New and rare elicitors of food allergy. Allergologie 2019, 42, 83-90. [CrossRef]

47. Zevallos, V.F.; Ellis, H.J.; Suligoj, T.; Herencia, L.I.; Ciclitira, P.J. Variable activation of immune response by quinoa (Chenopodium quinoa Willd.) prolamins in celiac disease. Am. J. Clin. Nutr. 2012, 96, 337-344. [CrossRef] [PubMed]

48. Di Maro, A.; Terracciano, I.; Sticco, L.; Fiandra, L.; Ruocco, M.; Corrado, G.; Parente, A.; Rao, R. Purification and characterization of a viral chitinase active against plant pathogens and herbivores from transgenic tobacco. J. Biotechnol. 2010, 147, 1-6. [CrossRef] [PubMed]

49. Landi, N.; Pacifico, S.; Ragucci, S.; Iglesias, R.; Piccolella, S.; Amici, A.; Di Giuseppe, A.M.A.; Di Maro, A. Purification, characterization and cytotoxicity assessment of Ageritin: The first ribotoxin from the basidiomycete mushroom Agrocybe aegerita. Biochim. Biophys. Acta Gen. Subj. 2017, 1861 Pt A, 1113-1121. [CrossRef]

50. Di Maro, A.; Ferranti, P.; Mastronicola, M.; Polito, L.; Bolognesi, A.; Stirpe, F.; Malorni, A.; Parente, A. Reliable sequence determination of ribosome-inactivating proteins by combining electrospray mass spectrometry and Edman degradation. J. Mass. Spectrom. 2001, 36, 38-46. [CrossRef]

51. Landi, N.; Ragucci, S.; Russo, R.; Pedone, P.V.; Chambery, A.; Di Maro, A. Structural insights into nucleotide and protein sequence of Ageritin: A novel prototype of fungal ribotoxin. J. Biochem. 2019, 165, 415-422. [CrossRef]

52. Di Giuseppe, A.M.A.; Russo, L.; Russo, R.; Ragucci, S.; Caso, J.V.; Isernia, C.; Chambery, A.; Di Maro, A. Molecular characterization of myoglobin from Sciurus vulgaris meridionalis: Primary structure, kinetics and spectroscopic studies. Biochim. Biophys. Acta Proteins Proteom. 2017, 1865, 499-509. [CrossRef] [PubMed]

53. Kumar, S.; Stecher, G.; Li, M.; Knyaz, C.; Tamura, K. MEGA X: Molecular Evolutionary Genetics Analysis across Computing Platforms. Mol. Biol. Evol. 2018, 35, 1547-1549. [CrossRef] [PubMed]

54. Yang, J.; Yan, R.; Roy, A.; Xu, D.; Poisson, J.; Zhang, Y. The I-TASSER Suite: Protein structure and function prediction. Nat. Methods 2015, 12, 7-8. [CrossRef] [PubMed]

55. Pettersen, E.F.; Goddard, T.D.; Huang, C.C.; Couch, G.S.; Greenblatt, D.M.; Meng, E.C.; Ferrin, T.E. UCSF Chimera-A visualization system for exploratory research and analysis. J. Comput. Chem. 2004, 25, 1605-1612. [CrossRef] [PubMed]

56. Gooding, G.V., Jr.; Hebert, T.T. A simple technique for purification of tobacco mosaic virus in large quantities. Phytopathology $1967,57,1285$.

57. Montalbini, P.; Polverari, A. Characterization of a tobacco necrosis virus strain isolated from tomato leaves. Phytopathol. Mediterr. 1996, 35, 105-110.

58. Baer, A.; Kehn-Hall, K. Viral concentration determination through plaque assays: Using traditional and novel overlay systems. J. Vis. Exp. 2014, 93, e52065. [CrossRef]

59. Schlumbaum, A.; Mauch, F.; Vögeli, U.; Boller, T. Plant chitinases are potent inhibitors of fungal growth. Nature 1986, 324, 365-367. [CrossRef] 